\title{
Grupo de Jornal: Abordagem Terapêutica Sociocultural na Reabilitação dos Transtornos Mentais
}

\author{
Lima, Adriane Bacellar Duarte; Sant, Renato Del \\ Hospital Dia do Ipq-HCFMUSP — adrianebd@uol.com.br
}

Introdução: a experiência de adoecimento decorre, muitas vezes, em desinteresse ou afastamento do mundo externo, acentuando-se as vivências autísticas. com as novas diretrizes de Atenção à Saúde Mental, modalidades de atendimento vem sendo redefinidas, voltadas não somente para a remissão sintomatológica, mas levando em consideração o resgate da cidadania e a reinserção psicossocial do individuo. Nesse sentido, a ênfase na criação de serviços que privilegiam a interação social tem sido fundamental. o tratamento passou a incluir abordagens e métodos terapêuticos grupais que estimulam 0 desenvolvimento de potencialidades, da autonomia e da subjetividade, procurando reduzir o impacto que a doença mental traz. o grupo de jornal é uma atividade terapêutica de um centro de tratamento interdisciplinar para doentes mentais. Objetivos: Ampliar o contato do paciente com a realidade imediata e cotidiana, bem como trabalhar a organização interna e estimular cognitivamente o individuo como um ser sociocultural. Métodos: a atividade é desenvolvida em um espaço aberto de convivência, com duração de uma hora, coordenada pela psicóloga da equipe interdisciplinar e colaboradoras. Num primeiro momento, os pacientes escolhem temas de relevância, que aconteceram durante a semana. a seguir, procura-se no jornal as notícias relacionadas, que são lidas em voz alta para todos, ampliando o repertório sobre o assunto. Todos são estimulados a participar verbalmente, buscando uma comunicação colaborativa. a etapa final do grupo destina-se às matérias a serem escolhidas e escritas pelos pacientes. o prazo de entrega, depende da capacidade de execução de cada paciente ao longo do mês. Toda semana, discute-se a evolução do material. Os pacientes têm acesso à internet para as pesquisas individuais e recebem suporte das psicólogas. Prontas, as matérias são afixadas em um mural. Resultados: Além do exercício de socialização e incremento cultural, há uma melhora da iniciativa, motivação, concentração e organização mental. Observa-se que o paciente adquire autonomia para desenvolver seu trabalho de acordo com suas condições psíquicas e intelectuais, a partir da ampliação do contato com a realidade imediata e cotidiana. Temos observado ainda, uma mudança na auto estima dos pacientes, que se apropriam novamente da sua capacidade de pensar sobre o mundo e se tornam sujeitos de uma ação produtiva que fica literalmente impressa no ambiente. Conclusões: Promover a reinserção social, implica no desenvolvimento de novas formas de se comunicar e se expressar, interagir com o outro, posicionar-se no ambiente, fazendo parte de um universo social, não mais pela patologia. o grupo de jornal é uma ferramenta legítima no tratamento das pessoas com transtorno mental.

Lima, Adriane Bacellar Duarte; Sant, Renato Del. Grupo de Jornal: Abordagem Terapêutica Sociocultural na Reabilitação dos Transtornos Mentais. In: Anais do Congresso Internacional de Humanidades \& Humanização em Saúde [= Blucher Medical Proceedings, num.2, vol.1]. São Paulo: Editora Blucher, 2014. ISSN 2357-7282

DOI 10.5151/medpro-cihhs-10617 